\title{
CHANGES IN SOIL ORGANIC MATTER UNDER DIFFERENT LAND MANAGEMENT IN MISIONES PROVINCE (ARGENTINA)
}

\author{
Gabriel Agustín Piccolo; Adrián Enrique Andriulo²*; Bruno Mary³ \\ ${ }^{1}$ INTA, EEA Cerro Azul, C.C. 6 (3313) Misiones - Argentina. \\ ${ }^{2}$ INTA, EEA Pergamino, Ruta32, km 4.5, (2700) Pergamino - Argentina. \\ ${ }^{3}$ INRA, Unité d'Agronomie de Laon-Reims-Mons, rue Fernand Christ, 02007 Laon - France. \\ *Corresponding author <andriulo@pergamino.inta.gov.ar>
}

ABSTRACT: Highly weathered tropical soils rapidly loose soil organic matter (SOM) and may be affected by water erosion and soil compaction after deforestation and intensive cultivation. With the main objective to estimate the SOM balances in a subtropical soil we determined the dynamics of SOM in a degraded yerba mate (Ilex paraguaiensis Saint Hil.) plantation introduced after deforestation and with elephant grass (Pennisetum purpureum L.) as a cover crop. The study site was in Misiones, Argentina, and we use the natural ${ }^{13} \mathrm{C}$ abundance methodology and a descriptive model. The study was conducted on three contiguous $50 \times 100 \mathrm{~m}$ plots of a typic Kandihumult soil with: (i) native forest, (ii) 50 years of continuous yerba mate monoculture with intensive tillage, and (iii) yerba mate associated with elephant grass as a cover crop and no tillage. We determined bulk density, carbon (C), nitrogen $(\mathrm{N})$ and ${ }^{13} \mathrm{C}$ content of the soil $(0-0.05,0.05-0.15 \mathrm{~m}$ layers $)$ and the grass biomass. Yerba mate monoculture reduced soil $\mathrm{C}$ and $\mathrm{N}$ content as well as porosity at $0-0.15 \mathrm{~m}$ depth by 43 and $23 \%$, respectively, as compared to the native forest. After ten years of yerba mate - elephant grass association soil $\mathrm{C}$ and $\mathrm{N}$ contents at the same depth increased by 19 and 12\%, respectively, compared to the yerba mate monoculture, while soil porosity remained similar. Total $\mathrm{C}$ input, ${ }^{13} \mathrm{C}$, and soil organic $\mathrm{C}$ were incorporated into a three compartment model to evaluate elephant grass $\mathrm{C}$ dynamics. Through the natural ${ }^{13} \mathrm{C}$ abundance methodology we tracked the elephant grass $\mathrm{C}$ incorporation and the "old” soil $\mathrm{C}$ loss, and determined the model parameters - humification $\left(k_{1}\right)$ and mineralization $(k)$ coefficients and stable $\mathrm{C}\left(C_{s}\right)$ - unambiguously. The high $k_{1}$ and $k$ predicted by the model are probably explained by elephant grass root system incorporation under no tillage and humid subtropical climate, respectively. In soil under yerba mate monoculture, $C_{s}$ was counted as $91 \%$ of the total soil organic C.

Key words: Ilex paraguaiensis, Pennisetum purpureum, natural ${ }^{13} \mathrm{C}$ abundance, soil carbon, modelling

\section{MUDANÇAS NAMATÉRIA ORGÂNICAEDAFICASOB DIFERENTES MANEJOS DE SOLO NA PROVÍNCIA DE MISIONES (ARGENTINA)}

RESUMO: Os solos altamente intemperizados dos trópicos perdem rapidamente matéria orgânica do solo (SOM) e podem ser afetados pela erosão hídrica e compactação depois de seu deflorestamento e agricultura contínua. O objetivo foi determinar a dinâmica da matéria orgânica do solo com capimelefante (Pennisetum purpureum L.) em um Kandihumult da província de Misiones (Argentina) após desmatamento e cultivo contínuo de erva-mate (Ilex paraguaiensis Saint Hil.), utilizando a metodologia da abundância natural em carbono $13\left({ }^{13} \mathrm{C}\right)$ e um modelo descritivo. O estudo foi conduzido em três parcelas contíguas de $50 \times 100 \mathrm{~m}$. As situações comparadas foram: (a) floresta nativa, e (b) local com 50 anos de monocultivo intensivo de erva- mate, e (c) erva-mate associada com capim-elefante como cultivo de cobertura sob plantio direto. Determinaram-se os conteúdos de carbono (C), de nitrogênio (N) e de ${ }^{13} \mathrm{C}$ e a densidade aparente do solo (camadas 0 - 0,05 e 0.05 - 0,15 m) e a biomassa da gramínea. Depois de 50 anos de monocultivo de erva-mate, os conteúdos de $\mathrm{C}$ e $\mathrm{N}$ e a porosidade da camada 0 - 0,15 m da floresta nativa diminuíram em 42, 47 e 23\%, respectivamente. Depois de 10 anos de associação erva-mate - capim-elefante, os conteúdos de $\mathrm{C}$ e $\mathrm{N}$ do solo e na mesma profundidade aumentaram em relação ao monocultivo de erva-mate em 19 e 12\%, respectivamente, mas a porosidade não foi modificada. $\mathrm{O}$ aporte de $\mathrm{C}$, o ${ }^{13} \mathrm{C}$ e o $\mathrm{C}$ orgânico total do solo foram incorporados em um modelo de três compartimentos para avaliar a dinâmica do $\mathrm{C}$ proveniente do capim-elefante. A metodologia da abundância natural em ${ }^{13} \mathrm{C}$ permitiu traçar a incorporação do $\mathrm{C}$ proveniente do capim-elefante e a perda do C "velho" no solo, e determinar sem ambigüidade os parâmetros do modelo: coeficiente de 
humificação $\left(k_{1}\right)$, coeficiente de mineralização da fração ativa de $C(k)$ e o $C$ estável $\left(C_{s}\right)$. Os altos valores de $k_{1}$ e $k$ preditos pelo modelo foram atribuídos à alta contribuição do sistema radicular do capim-elefante sob plantio direto e ao clima subtropical úmido, respectivamente. No solo sob monocultivo de erva-mate, $C_{s}$ representou $91 \%$ do C orgânico total do solo.

Palavras-chave: Ilex paraguaiensis, Pennisetum purpureum, abundância natural em ${ }^{13} \mathrm{C}$, carbono do solo, modelização

\section{INTRODUCTION}

Soil organic matter (SOM) is an important determinant of tropical soils fertility (Tiessen et al., 1994) and the main carbon (C) storage in terrestrial ecosystems (Post et al., 1982; Eswaran et al., 1993; TSBFCIAT, 2004; Zingore et al., 2005). Highly weathered soils of the tropics are characterized by a rapid decline in SOM when land is cleared for cultivation on a slash-burn crop sequence (Ogle et al., 2005; Jimenez \& Lal, 2006). Deforestation is frequently accompanied by loss of essential nutrients through soil erosion and by soil compaction (Eneji et al., 2003; Cerri et al., 2007), particulary in Misiones (NE Argentina), where about 200,000 ha of yerba mate (Ilex paraguaiensis Saint Hil.) have been planted. SOM and fertility loss following clear-cutting have been reported for the soils of Misiones (Piccolo et al., 1998) and fifty percent of the soils under yerba mate are affected by moderate or severe water erosion (Grúner, 1955; Musto et al., 1983; Casas et al., 1988). It is necessary to develop local sustainable agriculture systems that minimize SOM losses and optimize the inputs efficiency. Grasses add large amounts of SOM in the soil. Elephant grass (Pennisetum purpureum L.), a frequently used grass for cover crops (Opara-Nadi, 1993; Scopel et al., 2004), was introduced in NE Argentina in the last few years,

Soil C balance under grasses depends on the stability of the SOM derived from the previous vegetation, the rates of SOM input from the new established grass and its stability. When trees and shrubs (dominantly $\mathrm{C}_{3}$ species) are replaced by grasses (predominantly $\mathrm{C}_{4}$ ) it is possible to determine the origin of the SOM from its isotopic composition (Balesdent et al., 1987; Chonè et al., 1991; Bonde et al., 1992; McDonagh et al., 2001; Roscoe et al., 2004; Desjardins et al., 2004; Schwendenmann \& Pendall, 2006). Furtherover, the use of ${ }^{13} \mathrm{C}$ natural abundance technique together with simple mathematical approaches have further improved SOM turnover studies (Noordwijk et al., 1997; Bernoux et al., 1998; Wynn et al., 2006).

The main objective of this study was to compare the dynamics of the stable and labile $\mathrm{C}$ pools of SOM, using the ${ }^{13} \mathrm{C}$ abundance technique in: (i) native forest, (ii) degraded yerba mate plantation and (iii) a similar plantation associated with elephant grass. We also propose a descriptive model to estimate the stable
$\mathrm{C}$ fraction and the annual humification and mineralization rates of the active $\mathrm{C}$ fraction.

\section{MATERIAL AND METHODS}

\section{Site description}

The study was carried out in Oberá, Misiones province, Argentina ( $54^{\circ} 80^{\prime} \mathrm{W} 26^{\circ} 40^{\prime}$ S, $350 \mathrm{~m}$ above sea level). The soil is a Typic Kandihumult; it is highly weathered, red in color and rich in low activity clays $(\approx 57 \%)$. The climate is sub-tropical humid with no dry season (mean annual precipitation is $1,970 \mathrm{~mm}$ ) and the regional mean temperature of the coldest and warmest months is 15.6 and $25.5^{\circ} \mathrm{C}$, respectively. Landscape relief is considered as rolling.

The study was conducted in three adjacent 50 $\times 100 \mathrm{~m}$ plots, selected for their uniformity in soil profile development. The three plots are at the same topographical position (mid-hillslope with very long $c a .1 \%$ slopes) in order to avoid differences in the initial soil profiles that could confound treatment effects. Fertilizer and lime were not applied in the studied sites.

The systems compared were: (i) Virgin soil with the typical subtropical forest (Trichilia elegans, Ocotea acutifolia, Nectandra saligna, Balfourodendrum riedelianum, Chrisophilum marginatum, Matayba eleagnoides, Cabralea oblongifolia, Apuleia leocarpa, Inga afnis, Lonchocarpus leucanthus, Loncocarpus muehlbergianus, Cedrela forsilis, trichilia catigua (Cabrera, 1976). Extraction of the more valuable species enabled the establishment of new ones, maintaining constant the number of species. (ii) A fifty-year yerba mate monoculture. Weeds between rows were continuously controlled with disk-harrow to $0.15 \mathrm{~m}$ depth and herbicide. The excessive weed control favored the pruning of yerba mate roots. Leaves and branches of yerba mate were harvested every year leaving scarce surface residue. (iii) A ten-year yerba mate - elephant grass association with no tillage. The elephant grass was inter-cropped on a fifty-year plantation ten years before this study. During summer-time the grass had been cut three times a year and left on the soil surface as a mulch cover.

\section{Sample collection and analysis}

Soil sampling was done at the time of the elephant grass implantation and at six and ten years later 
in the three situations. Four samples of forest litter, elephant grass mulch and yerba mate residues were collected from each plot using a $0.25 \mathrm{~m}^{2}$ ring sampler. Four composite soil samples (of seven sub samples each) were extracted from each system at 0 - 0.05, $0.05-0.15 \mathrm{~m}$, and also at $0.15-0.30$ and 0.30 - $0.60 \mathrm{~m}$ under the forest. The $0-0.15 \mathrm{~m}$ depth corresponds to the $\mathrm{A}$ horizon and the two others to the B1 and part of B21 horizons, respectively. Sampling depths were chosen considering that SOM does not differ between these systems below the $0.05 \mathrm{~m}$ (Morrás \& Piccolo, 1998) and that soil tillage was always superficial $(\leq 0.15 \mathrm{~m})$. Samples were dried at $70^{\circ} \mathrm{C}$, passed through a $0.002 \mathrm{~m}$ sieve to remove plant residues and mortar ground to pass through a $0.0001 \mathrm{~m}$ sieve. $\mathrm{C}, \mathrm{N}$ and ${ }^{13} \mathrm{C}$ contents were determined with a mass spectrometer (Fisons/Isochrom). A $2.50 \mathrm{~m}$ long ditch was dug in each system and four soil cores ( $\cong 0.07 \mathrm{dm}^{3}$ ) were extracted at the same sampling depths to determine soil bulk density.

Elephant grass $\mathrm{C}$ and $\mathrm{N}$ inputs were calculated as the product between biomass (aerial + root) and total $\mathrm{C}$ and $\mathrm{N}$ concentrations. Elephant grass biomass was measured during its sixth year after implantation, when it had reached constant biomass production, by harvesting $0.5 \mathrm{~m}^{2}$ before each cut. Roots from the 0 - $0.15 \mathrm{~m}$ soil layer were collected (from the same surface area) and separated from the bulk soil using a fine jet of water, on a stacked sieve ( $0.2 \mathrm{~mm}$ mesh screen) set above a sedimentation vat. Then they were dried at $70^{\circ} \mathrm{C}$ for two days, weighed and ground to a fine powder. $\mathrm{C}$ and $\mathrm{N}$ concentration were determined by dry combustion using the same mass spectrometer.

Measurements of natural $\delta^{13} \mathrm{C}$ abundance were used to establish the origin of the SOM in each system using the technique developed by Cerri et al. (1985) and Balesdent et al. (1987). The proportion of soil C derived from elephant grass residues $\left(\alpha_{p}\right)$ was calculated as:

$\alpha_{P}(\%)=\left[\left(\delta_{m}-\delta_{F}\right) /\left(\delta_{P}-\delta_{F}\right)\right] \cdot 100$

where $\delta_{m}$ and $\delta_{F}$ are the $\delta^{13} \mathrm{C}$ values of the yerba mate - elephant grass association and the yerba mate monoculture soils, respectively, and $\delta_{P}$ is the $\delta^{13} \mathrm{C}$ value of the elephant grass material. $\delta_{F}$ was measured in soil samples from the yerba mate monoculture before elephant grass implantation because it is in this soil that elephant grass is introduced.

The $\mathrm{C}$ contents ( $\mathrm{g} \mathrm{kg}^{-1}$ soil) derived from elephant grass residues $\left(C_{D P}\right)$ and native forest $\left(C_{D F}\right)$ was calculated as:

$C_{D P}=\alpha_{P} \cdot C_{m}$
$C_{D F}=\left(1-\alpha_{P}\right) \cdot C_{m}$

where $C_{m}$ represents the total $\mathrm{C}$ content of bulk soil (g kg ${ }^{-1}$ soil)

The C stocks (total, originated from elephant grass and from native forest, in $\mathrm{Mg} \mathrm{ha}^{-1}$ ) were calculated using the equation (4):

$C=C_{x} \cdot d \cdot \rho \cdot 10$

where $C_{x}$ represents $C_{m}, C_{D P}$ or $C_{D F}, d$ is the depth (m) and $\rho$ is the bulk density $\left(\mathrm{Mg} \mathrm{m}^{-3}\right)$ of the corresponding soil depth. The same equation was used for soil $\mathrm{N}$ stock.

To study the dynamics of $\mathrm{C}$ under the association of yerba mate and elephant grass, the model proposed by Andriulo et al. (1999) was used. In this three-compartment model (Figure 1), SOM is separated into stable and active fractions and the evolution of the $\mathrm{C}$ stock is described by the following equation:

$C_{m t}=C_{s}+C_{a 0} \cdot e^{-k t}+\left(m k_{1} / k\right) \cdot\left(1-e^{-k t}\right)$

For time $(\mathrm{t})=0$

$C_{m 0}=C_{s}+C_{a 0}$

$q=k_{1} \cdot m$

$C_{\text {meq }}=C_{\text {max }}+C_{s}$

where $C_{s}$ is the stable $\mathrm{C}$ content $\left(\mathrm{Mg} \mathrm{ha}^{-1}\right), C_{a 0}$ is the initial active $\mathrm{C}$ content $\left(\mathrm{Mg} \mathrm{ha}^{-1}\right), C_{m 0}$ is the initial total $\mathrm{C}$ content $\left(\mathrm{Mg} \mathrm{ha}^{-1}\right), m$ is the annual mass of $\mathrm{C}$ input $\left(\mathrm{Mg} \mathrm{ha}^{-1}\right.$ year $\left.^{-1}\right), k_{1}$ is the humification or isohumic coefficient (unit-less), $k$ is the annual coefficient of mineralization of the active fraction (year ${ }^{-1}$ ), $q$ is the mass of $\mathrm{C}$ humifed annually ( $\mathrm{Mg} \mathrm{ha}^{-1}$ year ${ }^{-1}$ ), $\mathrm{C}_{\max }$ is the maximum quantity of soil $\mathrm{C}$ originated from elephant grass $\left(\mathrm{Mg} \mathrm{ha}^{-1}\right)$ and $\mathrm{C}_{\text {meq }}$ is the total quantity of soil C at equilibrium $\left(\mathrm{Mg} \mathrm{ha}^{-1}\right)$.

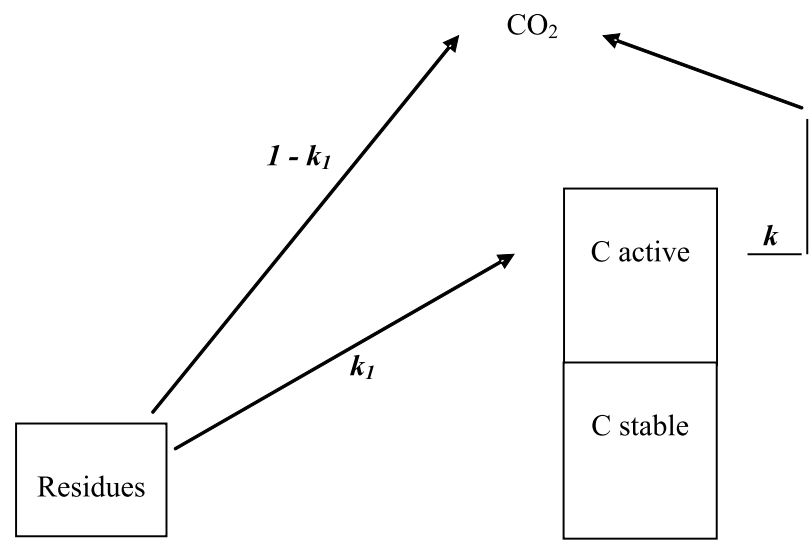

Figure 1 - Diagram of the three-compartment model of soil C evolution. $k_{1}=$ crop residues humification coefficient. $k=$ annual coefficient of mineralization of active SOM. 
Natural ${ }^{13} \mathrm{C}$ isotopic abundance was used to estimate the size of the model compartments and their evolution. The model considers the changes in "old" $\mathrm{C}$ stock $\left(\mathrm{C}_{1}\right)$, originated from forest, and "young" $\mathrm{C}$ stock $\left(\mathrm{C}_{2}\right)$, originated from elephant grass, separately. Contribution of yerba mate was considered null. Then, equation (5) can be separated in two terms:

$C_{\mathrm{mt}}=C_{1}+C_{2}$

with $C_{1}=C_{s}+C_{a 0} \cdot e^{-k t}$

and $C_{2}=\left(m k_{1} / k\right) \cdot\left(1-e^{-k t}\right)$

The term $C_{l}$ describes the decrease of the $\mathrm{C}$ content present at time zero; we call it "old C", since it includes the stable carbon pool $C_{s}$. The term $C_{2}$ represents the net amount of active carbon produced since time

zero.

We have fitted the two models simultaneously, by minimizing the sums of squares of model deviations for the variables $C_{1}$ and $C_{2}$. Whilst optimizing, we have taken into account the variance of the data by weighting the sums of squares of deviations. The following quantity (unitless) was minimized:

$Q=\left(S S Q_{1} / s_{1}^{2}\right)+\left(S S Q_{2} / s_{2}^{2}\right)$

where $S S Q_{1}$ and $S S Q_{2}$ are the sums of squares of deviations (calculated - simulated) of $C_{1}$ and $C_{2}$, respectively and $s_{1}^{2}$ and $s_{2}^{2}$ are the mean calculated variances obtained for $C_{1}$ and $C_{2}$, respectively. Fitting was performed by fixing $C_{m 0}$ and $m$ and optimizing three parameters: $C_{s}, k_{1}$ and $k$.

Carbon and $\mathrm{N}$ contents, bulk density and natural $\delta^{13} \mathrm{C}$ abundance at $0-0.05$ and $0.05-0.15 \mathrm{~m}$ soil depths and $\mathrm{C}$ and $\mathrm{N}$ stocks at $0-0.15 \mathrm{~m}$ were compared among systems using the Student test. Statistical significance were considered at $P<0.05\left(^{*}\right)$ and $\left.P<0.01{ }^{* *}\right)$.

\section{RESULTS AND DISCUSSION}

Mean soil C (N) stocks ( 0 - $0.15 \mathrm{~m}$ soil depth) of the yerba mate monoculture and the yerba mate elephant grass association were $50-70 \%$ of those from the natural forest (Table 1). These results demonstrate the rapid decrease in the SOM reserves of this tropical highly weathered soil under management. The $\mathrm{C}$ and $\mathrm{N}$ content of the forest soil was three and two times larger than the one under continuous yerba mate cultivation in the $0-0.05$ and $0.05-0.15$ $\mathrm{m}$ layers, respectively. Forest soil bulk density was 65 and $78 \%$ lower than in the yerba mate monoculture in the $0-0.05$ and $0.05-0.15 \mathrm{~m}$ layers, respectively. The sharp decrease in $\mathrm{C}$ and $\mathrm{N}$ content and in soil porosity following the slash and burn crop sequence is typical of tropical low activity-clay soils (Casas et al., 1983; Gupta et al., 1989; Cerri et al., 2007) due to the low dry matter input and continuous mechani-

Table 1 - Studied properties of a Kandihumult soil under three different soil management treatments in Misiones, Argentina.

\begin{tabular}{|c|c|c|c|c|c|c|c|c|c|}
\hline \multirow[t]{2}{*}{ Soil variables } & \multirow[t]{2}{*}{ Depth (m) } & \multicolumn{2}{|c|}{ Natural forest } & \multicolumn{2}{|c|}{$\begin{array}{c}50 \text { year - yerba } \\
\text { mate } \\
\text { monoculture }\end{array}$} & \multicolumn{2}{|c|}{$\begin{array}{l}6 \text { year - yerba } \\
\text { mate - elephant } \\
\text { grass association }\end{array}$} & \multicolumn{2}{|c|}{$\begin{array}{l}10 \text { year - yerba } \\
\text { mate - elephant } \\
\text { grass association }\end{array}$} \\
\hline & & Average & SD & Average & SD & Average & SD & Average & SD \\
\hline \multirow{4}{*}{ Soil C $\left(\mathrm{g} \mathrm{kg}^{-1}\right)$} & $0-0.05$ & $53.6 \mathrm{a}^{*}$ & 15.3 & $18.4 \mathrm{c}$ & 1.4 & $22.9 \mathrm{~b}$ & 1.3 & $24.9 \mathrm{~b}$ & 2.4 \\
\hline & $0.05-0.15$ & $32.7 \mathrm{a}$ & 1.9 & $15.5 \mathrm{c}$ & 1.1 & $16.2 \mathrm{bc}$ & 1.1 & $17.2 \mathrm{~b}$ & 0.40 \\
\hline & $0.15-0.30$ & 19.1 & 1.2 & & & & & & \\
\hline & $0.30-0.60$ & 10.7 & 0.1 & & & & & & \\
\hline \multirow{4}{*}{ Soil N $\left(\mathrm{g} \mathrm{kg}^{-1}\right)$} & $0-0.05$ & $5.69 \mathrm{a}$ & 1.40 & $1.77 \mathrm{c}$ & 0.13 & $2.12 \mathrm{~b}$ & 0.14 & $2.24 \mathrm{~b}$ & 0.18 \\
\hline & $0.05-0.15$ & $3.60 \mathrm{a}$ & 0.18 & $1.56 \mathrm{c}$ & 0.11 & $1.68 \mathrm{bc}$ & 0.12 & $1.68 \mathrm{~b}$ & 0.02 \\
\hline & $0.15-0.30$ & 2.03 & 0.16 & & & & & & \\
\hline & $0.30-0.60$ & 1.08 & 0.02 & & & & & & \\
\hline \multirow{4}{*}{ Bulk density $\left(\mathrm{Mg} \mathrm{m}^{-3}\right)$} & $0-0.05$ & $0.88 \mathrm{a}$ & 0.08 & $1.35 \mathrm{~b}$ & 0.17 & $1.31 \mathrm{~b}$ & 0.14 & $1.31 \mathrm{~b}$ & 0.15 \\
\hline & $0.05-0.15$ & $1.08 \mathrm{a}$ & 0.06 & $1.39 \mathrm{~b}$ & 0.16 & $1.40 \mathrm{~b}$ & 0.13 & $1.40 \mathrm{~b}$ & 0.14 \\
\hline & $0.15-0.30$ & 1.29 & 0.04 & & & & & & \\
\hline & $0.30-0.60$ & 1.26 & 0.09 & & & & & & \\
\hline Soil C stock $\left(\mathrm{Mg} \mathrm{ha}^{-1}\right)$ & \multirow{2}{*}{$0-0.15$} & \multicolumn{2}{|l|}{58.9 a } & \multicolumn{2}{|l|}{$34.0 \mathrm{~b}$} & \multicolumn{2}{|l|}{$37.6 \mathrm{c}$} & \multicolumn{2}{|l|}{$40.4 \mathrm{~d}$} \\
\hline Soil N stock $\left(\mathrm{Mg} \mathrm{ha}^{-1}\right)$ & & \multicolumn{2}{|l|}{$6.4 \mathrm{a}$} & \multicolumn{2}{|l|}{$3.4 \mathrm{~b}$} & \multicolumn{2}{|l|}{$3.7 \mathrm{c}$} & \multicolumn{2}{|l|}{$3.8 \mathrm{c}$} \\
\hline
\end{tabular}

SD: standard deviation; *values followed by the same letter within a line do not differ (Student test at $P<0.05$ ). 
cal weed control that characterize most of the yerba mate plantations.

Although soil erosion was not measured in this study, it has been reported in Misiones under similar conditions: Casas et al. (1988) and SAGPyA (1995) found soil losses of $25 \mathrm{Mg} \mathrm{ha}^{-1}$ year $^{-1}$. Applying this rate of soil loss to our condition, we would have lost $1,250 \mathrm{Mg} \mathrm{ha}^{-1}$ after fifty years. Calculated soil mass from $0-0.30 \mathrm{~m}$ depth under forest $\left(3,455 \mathrm{Mg} \mathrm{ha}^{-1}\right)$ is similar to soil mass of the Ap horizon plus the soil mass loss under yerba mate cultivation $(2065+1250$ $=3375 \mathrm{Mg} \mathrm{ha}^{-1}$ ). Assuming this to be true, the original $\mathrm{C}$ and $\mathrm{N}$ stocks under forest were 83.5 and 9.0 $\mathrm{Mg} \mathrm{ha}^{-1}$, respectively. Then, soil organic C and $\mathrm{N}$ would have been lost not only by biological processes but also by water erosion. Soil erosion together with continuous machinery traffic could explain the higher bulk density measured in the soil under yerba mate monoculture as compared to the forest soil.

Soil C and N contents increased under elephant grass - yerba mate association in the $0-0.05 \mathrm{~m}$ soil layer after six years of grass implantation $(P<0.01)$ and in $0.05-0.15 \mathrm{~m}$ soil after ten years of grass implantation $(P<0.05)$. However, this SOM increase did not improve soil porosity. The increase in soil $\mathrm{C}$ and $\mathrm{N}$ with grass is mainly due to a great residue returned to the soil, including the belowground ones $(18.0 \pm 2$ and $5.3 \pm 0.3 \mathrm{Mg} \mathrm{ha}^{-1}$ year $^{-1}$ for aerial and root biomasses, respectively) and this has also been reported in other tropical soils (Scopel et al., 2004). Additionally, cover crop mulch associated with no tillage increases SOM in surface soil by reducing soil disturbance which favors the protection of soil aggregates from rapid oxidation and by modifying the local edaphic environment: bulk density, pore distribution, temperature, water and air regime that might also restrict SOM biodegradation (Puget \& Lal, 2004). Working in similar soils of Misiones, Morrás \& Piccolo (1998) found more aggregation and more SOM in the top $0.05 \mathrm{~m}$ of the soil and more aggregation degree but no differences in SOM content at $0.05-0.15 \mathrm{~m}$ soil depth after six years of elephant grass - yerba mate association as compared to a long term conventionally tilled yerba mate plantation. In contrast to temperate soils, the better aggregation in tropical soils does not lead to an increase in $\mathrm{C}$ sequestration: aggregates formed by mineral-mineral bindings form faster but also protect less $\mathrm{C}$ upon conversion to no tillage than aggregates in temperate soils (Six et al., 2002).

After ten years of elephant grass - yerba mate association, soil $\mathrm{C}$ storage was $6.4 \mathrm{Mg} \mathrm{ha}^{-1}$ higher than under yerba mate in the $0-0.15 \mathrm{~m}$ layer, i.e. an increase of $0.6 \mathrm{MgC} \mathrm{ha}^{-1}$ year ${ }^{-1}$. Our results are in accordance with other authors that found that more sus- tainable agricultural systems can lead to an annual C accumulation of $0.3-0.6 \mathrm{Mg} \mathrm{ha}^{-1}$ under humid subtropics and tropics (Pretty \& Ball, 2001). Soil N stock increased $0.4 \mathrm{Mg} \mathrm{ha}^{-1}$ after ten years of elephant grass yerba - mate association. Elephant grass is a luxury feeder of soil $\mathrm{N}$ due to its high protein content (1.67\% $\mathrm{N})$ and biomass production (23.3 $\mathrm{Mg} \mathrm{ha}^{-1}$ year $^{-1}$ ) (Goorahoo et al., 2005). Since we did not graze on the elephant grass and its leaves were cut and left on soil surface as mulch, it became a significant addition of $\mathrm{N}$ to the soil (389 $\mathrm{kg} \mathrm{ha}^{-1}$ year $^{-1}$ ). Therefore, elephant grass - yerba mate association should be considered a sustainable system because it increased the soil $\mathrm{C}$ and $\mathrm{N}$ stock in the upper $0.15 \mathrm{~m}$ on a short period of time due to the very important $\mathrm{C}$ and $\mathrm{N}$ annual contributions, and also to marked decrease on soil disturbance.

The $\delta^{13} \mathrm{C}$ values obtained for litter were similar for the forest and yerba mate plots because forest and yerba mate trees have the same $\mathrm{C} 3$ photosynthetic pathway while the $\delta^{13} \mathrm{C}$ value of elephant grass was in accordance with a $\mathrm{C} 4$ grass. $\delta^{13} \mathrm{C}$ values showed a consistent increase (7.0 \%) with depth in the forest soil profile (Table 2). This has been noted previously (Vitorello et al., 1989; Martin et al., 1990; Desjardins et al., 1994) and may be related to the isotopic fractionation occurring during humification (Balesdent et al., 1987; Martin et al., 1990).

In the soil under continuous yerba mate cultivation, the $0-0.05 \mathrm{~m}$ layer presented a high enrichment in $\delta^{13} \mathrm{C}(-30.05 \%$ in litter and $-22.47 \%$ in the $0-0.05 \mathrm{~m}$ soil depth). However, soil $\delta^{13} \mathrm{C}$ contents usually resemble closely those of the original plant tissues. A reasonable explanation for this result is the wash out of, at least, part of the original A1 horizon.

The proportion of $\mathrm{C}$ derived from elephant grass residues $\left(\alpha_{p}\right)$ increased with time in the $0-0.05$ and $0.05-0.15 \mathrm{~m}$ depths (Table 2). After ten years, $\alpha_{p}$ reached $39 \%$ and $11 \%$ of bulk $\mathrm{C}$ in the upper 0 0.05 and $0.05-0.15 \mathrm{~m}$ layers, respectively. Studies of pasture chronosequences in the Amazon Basin showed that large amounts of soil $\mathrm{C}$ of forest origin were maintained after several years of pasture: $65 \%$ of the SOM in the $0-0.20 \mathrm{~m}$ layer was of forest origin in a ten-year-old elephant grass pasture (Desjardins et al., 1994) and about $80 \%$ of the total soil $\mathrm{C}$ in the upper $0.30 \mathrm{~m}$ was originated from forest material after eight years of pasture (Bonde et al., 1992). In our study, the contribution of elephant grass material to the total C stock was smaller (20\% at 0 $0.15 \mathrm{~m}$; Table 2), probably due to a lower annual C input and/or to a microbial population of the degraded soil (yerba mate) not adapted to efficiently process the SOM. 
Table 2 - Natural soil ${ }^{13} \mathrm{C}$ abundance and proportion of soil C derived from elephant grass under three different soil management treatments in Misiones. Argentina.

\begin{tabular}{|c|c|c|c|c|c|c|c|c|}
\hline \multirow[t]{2}{*}{$\begin{array}{l}\text { Soil depth } \\
\text { (m) }\end{array}$} & \multicolumn{2}{|c|}{ Natural forest } & \multicolumn{2}{|c|}{$\begin{array}{c}50 \text { year - yerba } \\
\text { mate } \\
\text { monoculture }\end{array}$} & \multicolumn{2}{|c|}{$\begin{array}{c}6 \text { year - yerba } \\
\text { mate- elephant } \\
\text { grass association }\end{array}$} & \multicolumn{2}{|c|}{$\begin{array}{l}10 \text { year - yerba } \\
\text { mate - elephant } \\
\text { grass association }\end{array}$} \\
\hline & Average & $\mathrm{SD}$ & Average & $\mathrm{SD}$ & Average & $\mathrm{SD}$ & Average & SD \\
\hline \multicolumn{9}{|c|}{ Natural soil ${ }^{13} \mathrm{C}$ abundance. $\delta^{13} \mathrm{C}(\%)$} \\
\hline Litter & -28.85 & 0.03 & $-30.05 !$ & ND & & & -11.90 & ND \\
\hline $0-0.05$ & $-26.36 a^{*}$ & 0.20 & $-22.47 b$ & 0.43 & $-19.28 c$ & 0.59 & $-18.35 d$ & 0.34 \\
\hline $0.05-0.15$ & $-25.48 \mathrm{a}$ & 0.12 & $-22.60 b$ & 0.52 & $-21.74 b c$ & 0.59 & $-21.43 c$ & 0.36 \\
\hline $0.15-0.30$ & -24.34 & 0.21 & & & & & & \\
\hline $0.30-0.60$ & -21.56 & 0.18 & & & & & & \\
\hline \multicolumn{9}{|c|}{ Proportion of soil $\mathrm{C}$ derived from elephant grass. $\alpha_{D P}(\%)$} \\
\hline $0-0.05$ & & & 0.0 & & 30.2 & & 39.0 & \\
\hline $0.05-0.15$ & & & 0.0 & & 8.0 & & 10.9 & \\
\hline
\end{tabular}

SD: standard deviation; !: mean value from leaves and branches of yerba mate exported as yield; *means followed by the same letter within a line do not differ (Student test at $P<0.05$ ).

Figure 2 shows the evolution of $\mathrm{C}_{D P}$ and $\mathrm{C}_{D F}$ calculated by ${ }^{13} \mathrm{C}$ data and predicted using Andriulo et al. (1999) model. The same exponential kinetics, which take into account the hypothesis of a stable fraction of SOM, have been used in other SOM turnover studies (Jenkinson \& Rayner, 1977; Parton et al., 1987; Balesdent et al., 1988). The proposed model adjusted very well to the measured data $(\mathrm{Q}=0.11)$. As bulk density soil values did not change during ten years under elephant grass - yerba mate association, comparison of SOC stocks at fixed depth was appropriate between cultivated treatments. We assumed that water erosion became negligible with the elephant grass implementation. The model indicates that the $\mathrm{C}$ content at the equilibrium point (equation 8 ) would increase markedly $\left(C_{\text {meq }}=40 \mathrm{Mg} \mathrm{ha}^{-1}\right)$ because of the high quantity of humified SOM $\left(q=2.5 \mathrm{Mg} \mathrm{ha}^{-1}\right.$ year $\left.^{-1}\right)$ (equation 7). In fact, the predicted increase in $C_{D P}$ was very important (from 0 to $9.0 \mathrm{Mg} \mathrm{ha}^{-1}$ ), while the predicted decrease of the $C_{D F}$ was smaller (from 34 to $31 \mathrm{Mg} \mathrm{ha}^{-1}$ ). Humified SOM represented $26 \%$ of the annual applied C $\left(k_{1}=0.26\right)$. The $k_{1}$ values estimated in other studies range between 0.08 and 0.40 (Hénin \& Dupuis, 1945; Janssen, 1984; Jenkinson, 1990; Bolinder et al., 1999). In general, $k_{1}$ values for aboveground residues average 0.12 (Bolinder et al., 1999) and roots present higher $k_{1}$ values because of the higher lignin content and the physical protection imparted by soil aggregates (Bayer et al., 2006). The isohumic coefficient obtained in this study would be mainly due to grass abundant system under no tillage. The active fraction mineralized with a turnover (TRM) of $c a$. four years. The coefficient of mineralization $(k)$ of our model $\left(0.28\right.$ year $\left.^{-1}\right)$ may be compared with the

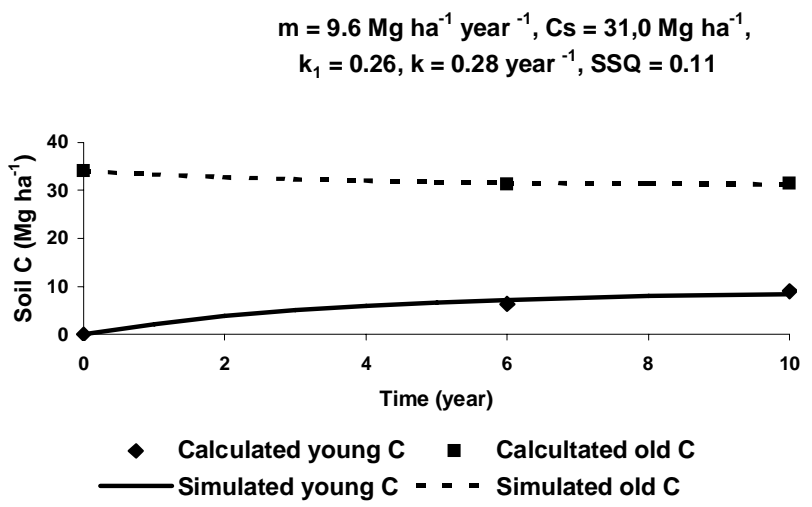

Figure 2 - Evolution of simulated and calculated old and young $C$ fractions of SOM (0-0.15 m layer) under ten years of continuous elephant grass - yerba mate association and after fifty years of yerba mate.

annual rate of SOC loss $\left(k_{2}\right)$ using equation 13 (Andriulo et al., 1999):

$k_{2}=k\left[C_{a} /\left(C_{a}+C_{s}\right)\right]$

The resulting $k_{2}$ is $\approx 0.06$ year $^{-1}$, which is in agreement with the climatic characteristics and texture of these soils. Bayer et al. (2006) reported a $k_{2}$ of 0.10 year $^{-1}$ in a tropical Ultisol of SE Brazil (São Paulo) where mean temperaturas are higher than in Misiones, and a $k_{2}$ of 0.01 year $^{-1}$ in a clayey ultisol (> 600 g clay $\mathrm{kg}^{-1}$ ) in another region of Brazil (Rio Grande do Sul) with lower temperatures and rainfall.

The model estimated that the organic $\mathrm{C}$ stock stabilized at $40 \mathrm{Mg} \mathrm{ha}^{-1}$. The active C pool represented $22 \%$ of the total $\mathrm{C}$ at the equilibrium level. Total $\mathrm{C}$ was $34 \mathrm{Mg} \mathrm{ha}^{-1}$ at $\mathrm{t}_{0}$ and $\mathrm{C}_{\mathrm{s}}$ was $31 \mathrm{Mg} \mathrm{ha}^{-1}$ (Figure 2 and Table 1). The difference between these two pools rep-

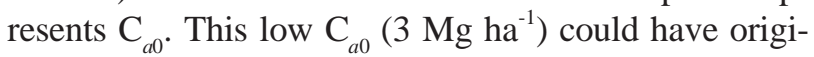


nated either from yerba mate root biomass or from forest after fifty years of continuous yerba mate cultivation. If the active fraction has a high turnover then, it would have disappeared unless the active soil $\mathrm{C}$ from forest soil was progressively exposed due to water erosion.

The use of natural abundance ${ }^{13} \mathrm{C}$ has proved to be a reliable method to follow the young $\mathrm{C}$ (from elephant grass) incorporation into the soil and the old $\mathrm{C}$ (from forest) evolution. Its combination with a simple model to describe decrease $\mathrm{C}$ kinetic from forest and accumulation $\mathrm{C}$ kinetic from elephant grass is promising. Although the descriptive model we used is easier to parameterize than other more powerful models which describe SOM bio-transformations taking into account a great number of parameters and compartments (Smith et al., 1997; Nicolardot et al., 2001; Petersen et al., 2005), the validation of this one in other experimental sites of the Ultisols of Misiones province is still pending. Thus it should be used carefully in long-term simulations, due to the need of continuous experimental data, particularly to establish the stable SOM pool size. Furthermore, the probable negative impact of water erosion on soil C content should be taken into account.

\section{ACKNOWLEDGEMENTS}

To Mr. Olivier Delfosse for the $\mathrm{C}, \mathrm{N}$ and ${ }^{13} \mathrm{C}$ determinations and M Sc. Silvina Portela for the English revision of this paper.

\section{REFERENCES}

ANDRIULO, A.; MARY, B.; GUÉRIF, J. Modeling soil carbon dynamics with various cropping sequences on the rolling pampas. Agronomie, v.19, p.365-377, 1999.

BALESDENT, J.; MARIOTTI, A.; GUILLET, B. Natural ${ }^{13} \mathrm{C}$ abundance as a tracer for soil organic matter dynamics studies. Soil Biology and Biochemistry, v.19, p.25-30, 1987.

BALESDENT, J.; WAGNER, G.H.; MARIOTTI, A. Soil organic matter turnover in long-term field experiments as revealed by carbon-13 natural abundance. Soil Science Society of American Journal, v.52, p.118-124, 1988.

BAYER, C.; LOVATO, T.; DIECKOW, J.; ZANATTA, J.A.; MIELNICZUK, J. A method for estimating coefficients of soil organic matter dynamics based on long-term experiments. Soil and Tillage Research, v.91, p.217-226, 2006.

BERNOUX, M.; CERRI, C.C.; NEILL, C.; MORAES, J.F.L. The use of stable carbon isotopes for estimating soil organic matter turnover rates. Geoderma, v.82; p.43-58, 1998.

BOLINDER, M.A.; ANGERS, D.A.; GIROUX, M.; LAVERDIERE, M.R. Estimating $C$ inputs retained as soil organic matter from corn (Zea mays L.). Plant and Soil, v.215, p.85-91, 1999.

BONDE, T.A.; CRISTENSEN, B.T.; CERRI, C.C. Dynamics of soil organic matter as reflected by natural ${ }^{13} \mathrm{C}$ abundance in particle size fractions of forested and cultivated oxisols. Soil Biology and Biochemistry, v.24, p.275-277, 1992.

CASAS, R.; MICHELENA, R.; LACORTE, S. Relevamiento de propiedades físicas y químicas de suelos sometidos a distintos usos en el sur de Misiones y NE de Corrientes. Cerro Azul: . INTA-EEA, 1983. 18p. (Nota Técnica, 35).
CASAS, R.; LEYES, M.; ABELARDO, S.; GUANES, E.; LACORTE, S.; CAPURRO, R. Provincia de Misiones. In: KUGLER W.F.; PREGO, A.J.; CANTERO GUTIERREZ, A.; CAPURRO, R.A.; GLAVE, A.E.; PANIGATTI, J.L. (Ed.) El deterioro del ambiente en la Argentina. Buenos Aires: República Argentina, 1988. cap.4, 130-135.

CABRERA, A.L. Regiones fitogeográficas argentinas. Buenos Aires: Acme, 1976. Tomo 2, 85p.

CERRI, C.C.; FELLER, C.; BALESDENT, J.; VICTORIA, R.; PLENECASSAGNE, A. Application du traçage isotopique naturel en ${ }^{13} \mathrm{C}$ à l'étude de la dynamique de la matière organique dans les sols. Compte Rendu de l'Académie des Sciences, Paris (Sér. II.), v.300, p.423-426, 1985.

CERRI, C.E.P.; SPAROVEK, G.; BERNOUX, M.; EASTERLING, W.E.; MELILLO, J.M.; CERRI, C.C.C. Tropical agriculture and global warming: impacts and mitigation options. Scientia Agricola, v.64, p.83-99, 2007.

CHONE, T.; ANDREUX, F.; CORREA, J.C.; VOLKOFF, B.; CERRI, C.C. Changes in organic matter in an oxisol from the Central Amazonian forest during eight years as pasture, determined by ${ }^{13} \mathrm{C}$ isotopic composition. In: BERTHELIN, J. (Ed.) Diversity of environmental biogeochemistry. New York: Elsevier, 1991. p.397-405.

DESJARDINS, T.; ANDREUX, F.; VOLKOFF, B.; CERRI, C.C. Organic carbon and ${ }^{13} \mathrm{C}$ contents in soils and soil size-fractions, and their changes due to deforestation and pasture installation in eastern Amazonia. Geoderma, v.61, p.103-118, 1994.

DESJARDINS, T.; BARROS, E.; SARRAZIN, M.; GIRARDIN, C.; MARIOTTI, A. Effects of forest conversion to pasture on soil carbon and dynamics in Brazilian Amazonia. Agriculture Ecosystems and Environment, v.103, p.365373, 2004.

ESWARAN, H.; BERG, E. van den; REICH, P. Organic carbon in soils of the world. Soil Science Society of America Journal, v.57, p.192-194, 1993.

ENEJI, A.E.; AGBOOLA, A.; AIYERLARI, E.A.; HONNA T.; YAMAMOTO, S.; IRSHAD, M.; ENDO, T. Soil physical and micronutrient changes following clearing of a tropical rainforest. Journal of Forestry Research, v.8, p.215-219, 2003.

GOORAHOO, D.; CASSEL F.S.; ADHIKARI, D.; ROTHBERG, M. Update on elephant grass research and its potential as a forage crop. Available at: http://alfalfa.ucdavis.edu/ +symposium/proceedings/asdf/alf_symp/2005/05-175.pdf. Accessed 10 Jun. 2006

GRÚNER, G. La erosión en Misiones. Buenos Aires: Ministerio de Agricultura y Ganadería, 1955. 70p. (Publicación Miscelánea, 441).

GUPTA, S.C.; SHARMA, P.P.; DE FRANCHI, S.A. Compaction effects on soil structure. Advances in Agronomy, v.42, p.311337, 1989

JANSSEN, B.H. A simple method for calculating decomposition and accumulation of "young" organic matter. Plant and Soil, v.76, p.597-604, 1984.

JENKINSON, D.S.; RAYNER, J.H. The turn-over of soil organic matter in some of the Rothamsted classical experiments. Soil Science, v.123, p.298-305, 1977.

JENKINSON, D.S. The turnover of soil organic carbon and nitrogen in soil. Philosophical Transactions of the Royal Society of London, v.329, p.361-368, 1990.

JIMENEZ, J.J.; LAL, R. Mechanisms of C sequestration in soils of Latin America. Critical Review in Plant Sciences, v.25, p.337-365, 2006.

MARTIN, A.; MARIOTTI, A.; BALESDENT, J.; LAVELLE. P.; VUATTOUX, R. Estimate of organic matter turnover rate in a savanna soil by ${ }^{13} \mathrm{C}$ natural abundance measurements. Soil Biology and Biochemistry, v.22, p.517-523, 1990.

McDONAGH, J.F.; BIRCH-THOMSEN, T.; MUGID, J. Soil organic matter decline and compositional change associated with cereal cropping in southern Tanzania. Land degradation and Development, v.12, p.13-26, 2001. 
MORRÁS, H.; PICCOLO, G. A. Biological recuperation of degraded Ultisols in the Province of Misiones, Argentina. Advances in GeoEcology, v.31, p.1211-1215, 1998.

MUSTO, J.C.; IRURTIA, C.; CULOT, M. Zonificación de los procesos erosivos en la región argentina de la Cuenca del Plata. IDIA, v.40, p.24-35, 1983.

NICOLARDOT, B.; RECOUS, S.; MARY, B. Simulation of C and N mineralization during crop residue decomposition: a simple dynamic model based on the C:N ratio of the residues. Plant and Soil, v.228, p.83-103, 2001.

NOORDWIJK, M. van; CERRI, C.C.; WOOMER, P.L.; NUGRROHO, K.; BERNOUUX, M. Soil carbon dynamics in the humid tropical forest zone. Geoderma, v.79, p.187-225, 1997.

OGLE, S.M.; BREIDT, F.J.; PAUSTIAN, K. Agricultural management impacts on soil organic carbon storage under moist and dry climatic conditions of temperate and tropical regions. Biogeochemistry, v.72, p.87-121, 2005.

OPARA-NADI, O.A. Effect of elephant grass and plastic mulches on soil properties and cowpea yield on an Ultisol in southeastern Nigeria. In: MULONGOY, K.; MERCKX, R. (Ed.) Soil organic matter dynamics and sustainability of tropical agriculture. Leuven: IITA/K.U, 1993. p.223-230.

PARTON, W.J.; SCHIMEL, D.S.; COLE, C.V.; OJIMA, D.S. Analysis of factors controlling soil organic matter levels in Great Plains grasslands. Soil Science Society of America Journal, v.51, p.1173-1179, 1987.

PETERSEN, B.M.; BERNTSEN, J.; HANSEN, S.; JENSEN, L. CNSIM: a model for the turnover of soil organic matter. I. Longterm carbon and radiocarbon development. Soil Biology and Biochemistry, v.37, p.359-374, 2005.

PICCOLO, G.A.; ROSELL, R.A.; GALANTINI, J.A.; MIGLIERINA, A.M. Transformaciones de la materia orgánica en un suelo laterítico (Misiones, Argentina): II. Cambios en la materia orgánica particulada y humificada. Agricultura Técnica, v.58, p.142-150, 1998.

POST, W.M.; EMANUEL, W.R.; ZINKE, P.J.; STANGENBERGER, A.G. Soil carbon pools and world life zones. Nature, v.298, p.156-159, 1982.

PRETTY, J.; BALL, A. Agricultural influences on carbon emissions and sequestration: a review of evidence and the emerging trading options. Available at: http:// www 2. es sex.ac.uk/ces/Res earchProgrammes/ CESOccasionalPapers/OccPaper2001-4.pdf . Accessed 26 Dec. 2005.

PUGET, P.; LAL, R. Soil organic carbon and nitrogen in a Mollisol in central Ohio as affected by tillage and land use. Soil and Tillage Research, v.80, p.201-213, 2004.

ROSCOE, R.; BUURMAN, P.; LAAGEN, B. van; VELTHORST, E. Transformation in occluded light fraction organic matter in clayey oxisol: evidence from ${ }^{13} \mathrm{C}$-CPMAS-NMR and $\delta^{13} \mathrm{C}$ signature. Revista Brasileira de Ciência do Solo, v.28, p.811818, 2004.
SCHWENDENMANN, L.; PENDALL, E. Effects of forest conversion into grassland on soil aggregate structure and carbon storage in Panama: evidence from soil carbon fractionation and stable isotopes. Plant and Soil, v.288, p.217-232, 2006.

SCOPEL, E.; TRIOMPHE, B.; RIBEIRO, M.F.S.; SEGUY, L.; DENARDIN, J.E.; KOCHHANN, R.A. Direct seeding mulchbased cropping systems (DMC) in Latin America. Available at:http://www.cropscience.org.au/icsc2004/2/2/1406_scopele. htm. Accessed 21 Jun. 2005.

SIX, J.; FELLER, C.; DENEF, K.; OGLE, S.M.; MORAES SA, J.C.; ALBRECHT, A. Soil organic matter, biota and aggregation in temperate and tropical soils: effects of no-tillage. Agronomie, v.22, p.755-775, 2002.

SMITH, P.; SMITH, J.U.; POWLSON, D.S.; McGILL, W.B.; ARAH, J.R.M.; CHERTOV, O.G.; COLEMAN, K.; FRANKO, U.; FROLKING, S.; JENKINSON, D.S.; JENSEN, L.S.; KELLY, R.H.; KLEIN-GUNNEWIEK, H.; KOMAROV, A.S.; LI, C.; MOLINA, J.A.E.; MUELLER, T.; PARTON, W.J.; THORNLEY, J.H.M.; WHITMORE, A.P. A comparison of the performance of nine soil organic matter models using datasets from seven long-term experiments. Geoderma, v.81, p.153-225, 1997.

TIESSEN, H.; CUEVAS, E.; CHACON, D. The role of soil organic matter in sustaining soil fertility. Nature, v.371, p.783-785, 1994.

TROPICAL SOIL BIOLOGY AND FERTILITY INSTITUT - TSBF. CENTRO INTERNACIONAL DE AGRICULTURA TROPICAL - CIAT. Available at: http//www.ciat.cgiar.org/ tsbf_institute/pdf/annual_report_2004/contents_2004.pdf. Accessed 18 Jun. 2005.

VITORELLO, V.A.; CERRI, C.C.; ANDREUX, F.; FELLER, C.; VICTORIA, R.L. Organic matter and natural carbon ${ }^{13} \mathrm{C}$ distribution in forested and cultivated Oxisols. Soil Science Society of America Journal, v.53, p.773-778, 1989.

WYNN, J.G.; HARDEN, J.W.; FRIES, T.L. Stable carbon isotope depth profiles and soil organic carbon dynamics in the lower Mississippi Basin. Geoderma, v.131, p.89-109, 2006.

ZINGORE, S.; MANYAME, C.; NYAMUGAFATA, P.; GILLER, K.E. Long-term changes in organic matter of woodland soils cleared for arable cropping in Zimbabwe. European Journal of Soil Science, v.56, p.727-736. 2005.

Received December 11, 2006

Accepted October 15, 2007 